\title{
The Construction of "Four Horizontal Lines and Four Vertical Lines" Curriculum Systems in College Accounting Major
}

\author{
Jie Ren \\ Department of Management \\ Tianjin College, University of Science \& Technology \\ Beijing \\ Tianjin, China \\ renjie5288@163.com \\ Yuan Zhang \\ Department of Management \\ Tianjin College, University of Science \& Technology \\ Beijing \\ Tianjin, China \\ 524596837@qq.com
}

\author{
Yu Yang \\ Department of Information \\ Tianjin College, University of Science \& Technology \\ Beijing \\ Tianjin, China \\ 519000605@qq.com
}

\author{
Binrong Wang* \\ Dongling School of Economics \& Management \\ University of Science \& Technology Beijing \\ Beijing, China \\ wangbr@manage.ustb.edu.cn
}

\begin{abstract}
As an important base for the formation of basic knowledge for accountants, colleges and universities have assumed their important mission. Taking Tianjin College, University of Science and Technology Beijing as an example, this paper analyzes the construction of accounting professional course system and its vertical and horizontal links. Research establishes a systematic "Four Horizontal Lines and Four Vertical Lines" accounting course group. It's based on the development needs of applied talents to form a network of accounting professional course groups. Put the accounting ability of cultivating students' sustainable development in a prominent position and explore new modes and ways of cultivating senior accountants.
\end{abstract}

Keywords - college education; accounting curriculum systems; vertical and horizontal links

\section{INTRODUCTION}

With the landing of the Beijing-Tianjin-Hebei integration strategy, the social structure, level requirements and application capacity requirements of professional knowledge of accounting personnel are also constantly improving. In order to make the system of accounting specialty in higher education meet the needs of social and economic development, this paper focuses on the setting of curriculum system of accounting major. In order to realize the horizontal connection between the four-year undergraduate knowledge, qualities and abilities. At the same time through the vertical. From the perspective of accounting profession's ability of cognition, comprehensive ability and ability of development, the coherence, step-by-step, comprehensiveness and applicability of accounting professional course group should be strengthened. The internal relations in the course are summarized, and the specific content and internal logical relationship of the accounting specialty course group are explored. It analyzes the syllabus, calendar and teaching plans of all courses in the course group, and finds out the longitudinal and lateral relations. Eliminate similar or repetitive teaching contents in the same vertical course, and supplement each other in the same horizontal module curriculum, so as to gradually improve the teaching content of curriculum group.

\section{The Current Situation of Constructing Accounting Course Group in COLLEges}

For a long time, China's higher education has not completely got rid of the inertia of thinking elite education, and has the theoretical feelings that can't be separated. From the formal point of view, the purpose of education is still to train teaching and scientific research personnel.

Based on this premise, the accounting profession of many colleges and universities formed a curriculum model centered on abstract theory. The curriculum system deviates from the real demands of graduates and feedback from the market. The application of personnel training objectives[1].

\section{A. The Triad Education Model Needs to Be Improved.}

At present, independent colleges in our country mainly focus on cultivating "applied" professionals. This article takes Tianjin College, University of Science and Technology Beijing as the research object, and analyzes the construction of the accounting professional course system and its horizontal and vertical linking.

From the perspective of knowledge gradient, the popular accounting professional course system divides the course into three basic modules: public basic course, basic course and professional course. From the point of view of choice, it is 
divided into three major modules: elective course, elective course and elective course[2].

A good curriculum structure must be in the appropriate proportion of each module in order to form a reasonable cognitive structure, can effectively drive students to more purpose and direction to train management skills.

Under the guidance of the training of applied talents, our school gradually turns to practice accounting education with the characteristics of imparting the basic theoretical knowledge of accounting and tries hard to achieve the education mode of 'teaching, learning and doing".

However, the curriculum system and organizational teaching do not give a clear longitudinal guidance on the accounting professional courses and the gradual and gradual progress of accounting career development, nor do they make a specific lateral classification of module courses in the same direction[3].

\section{B. The Course Settings Are Not Connected.}

Curriculum should be fully concerned about the progressive acceptance of students and accounting career development, professional curriculum group is to develop students professional and technical knowledge and ability to work an important carrier. It is sub-level, from the grass-roots level of accounting jobs required by the development of the group to the top accounting positions required course group.

The opening of accounting courses and teaching of accounting should not rigidly adhere to the tradition of teaching plan immutable, but should advance with the times, in line with the laws of students learning and social requirements of talent.

\section{College Accounting Professional Curriculum SERIES VERTICAL Classification}

By means of curriculum group construction, the integration of existing in the existing curriculum repeat parts and cohesion, to improve the teaching effect and improve accounting professional students' comprehensive application ability, strengthen students' employment competitive power as the ultimate goal[4].

The relevant teaching content involved in teaching level by level to achieve the progressive combination of theory and practice, to develop a solid foundation, high overall quality, adaptability and practical ability of applied talents.

The accounting profession focuses on enhancing teachers' devotion and dedication, and combining their academic interest with teaching practice, so that teachers can consciously achieve the integration and unification of scientific research, teaching and education. Make full use of the teacher's force, mentoring of teachers. At the same time, more exchanges, learning and creation, research opportunities and atmosphere for the outstanding young teachers, the teachers in the teaching and the scientific research and practice ability get all-round improvement, so as to create an enough quantity and high quality, rigorous efficient and steady team of teachers.

\section{A. A Longitudinal Series of Teaching Programs.}

Tianjin College, University of Science and Technology Beijing accounting professional teaching program longitudinal series of courses specifically for the content: the discipline based curriculum as a starting point, the establishment of professional compulsory, aided elective courses. At the same time pay attention to innovation and entrepreneurship and practical courses[5].

The aim is to develop a comprehensive mastery of accounting students' knowledge from a macro perspective and step by step progression-level professional courses to enable teachers and students to gain a deep understanding of the vertical position of the courses.

In the teaching organization, teachers must start from the bottom of the vertical accounting series course group to complete a level of curriculum teaching and ability training before they can rise to a new higher level.

\section{B. Financial Accounting Vertical Series Course Group}

Tianjin College, University of Science and Technology Beijing accounting professional financial accounting vertical series of courses specific content: basic accounting, basic accounting training courses as the basis, intermediate financial accounting courses as the core, advanced financial accounting as an advanced upgrade, combined with financial accounting theory, accounting history and other theoretical knowledge, applied to practice such as the practice of integrated accounting practice courses.

The purpose of this course is to sort out the core courses of accounting major and to form a gradual upgrade of the main course system, which is conducive to students' deep understanding of the core specialized courses[6].

\section{Accounting Positions Level Vertical Series Course Group}

Tianjin College, University of Science and Technology Beijing accounting professional post hierarchy courses group level relations as follows: grassroots accounting jobs $\rightarrow$ grassroots accounting management positions $\rightarrow$ middle accounting management positions $\rightarrow$ senior accounting management positions.

1) The basic accounting positions: university computer foundation, microeconomics $\mathrm{B}$, macroeconomics $\mathrm{B}$, basic accounting, financial laws and regulations and accounting professional ethics, management office automation principle and technology;

2) The basic accounting management positions: intermediate accounting practice, tax introduction, cost accounting, financial statement analysis, government and nonprofit organization accounting, financial accounting, the application of Excel in financial management, economic law, management principle, management information system of accounting simulation experiment, etc;

3) The intermediate accounting management positions: intermediate financial accounting, computerized accounting principles and practices, UF U8 software operation, auditing, financial management, asset evaluation, international finance, 
applied economic statistics, management accounting, accounting English, marketing

4) The senior accounting management positions: finance, investment, investment banking, multinational finance, advanced financial management, financial decision-making simulation training, project evaluation and management, human resources management.

Adhere to the principle of designing accounting course group and organizing accounting teaching according to the level of professional development[7].

According to accounting career ladder and gradual development characteristics, the corresponding module design accounting courses. Specifically speaking, based on the module of grassroots accounting positions, the module of middle-level accounting management posts is the core, and the module of high-level accounting management positions is spire. In the organization of accounting teaching, according to different modules from low to high levels of teaching.

\section{Vertical Series of Applied Practice Classes}

The vertical series of applied practice classes mainly include basic accounting training, U8 software operation of UF, accounting simulation experiment, and large practice of accounting comprehensive practice.

Aimed at the development characteristics of accounting practice education, and strive to achieve the "three-in-one education mode of teaching, learning and doing", the practice curriculum throughout the professional theory curriculum, in accordance with the ability to enhance the level of step by step, and ultimately enhance the application level of the students, "learn with director, use it.".

\section{COLLEGE ACCOUNTING COURSES HORIZONTAL CLASSIFICATION MODULE}

A good curriculum structure must be in the appropriate proportion of each module in order to form a reasonable cognitive structure, can effectively drive students to more purpose and direction to train management skills.

When setting up a professional course, it is often not enough to pay attention to the relationship between the courses, so that the courses are separate from each other.

First of all, the curriculum is unorganized and fragmented, without a complete knowledge chain.

The second is the timing of the course. Once again, there are serious repetitions between classes, resulting in wasted hours.

Finally, a knowledge module of the previous course is required to support the subsequent courses, but the previous courses have no corresponding foreshadowing.

\section{A. Accounting Class Horizontal Course Group}

Accounting class horizontal course group mainly includes: basic accounting, basic accounting training, intermediate financial accounting, cost accounting, taxation, accounting principles and practices of computerized, financial statements analysis, comprehensive accounting practice exercises and other courses. Designed to cultivate students' basic accounting ability, to meet all the professional functions of corporate grassroots accounting.

\section{B. Management Horizontal Module Courses Group}

Management class horizontal module course group includes: management principles, human resources management, management information systems, project evaluation and management, management office automation principles and techniques, financial management, management accounting courses.

The purpose is to deepen students' thinking in management science, comprehensively manage most of the major contents of the major categories, and develop their management abilities.

\section{Tax Law Related Class Module Transverse Course Group}

Transverse module courses for tax-related and law-related group mainly includes: introduction to economic law, tax, financial regulations and accounting professional ethics, financial accounting, the government and the nonprofit organization accounting, international finance.

It is proposed to increase tax accounting, tax planning and civil and commercial law and other elective courses. It aims to cultivate students' knowledge of tax and law related to accounting work, and expand the scope of knowledge horizontally to become interdisciplinary talents.

\section{Computer Operation Horizontal Module Courses Group}

Computer operating class horizontal module course group includes: university computer foundation B, FoxPro and its application, management information system, management office automation principle and technology, accounting computerized principle and practice, Excel in financial management application, UF U8 software Operation, financial decision-making simulation training.

Designed to cultivate students' comprehensive computer application capabilities, seamless integration with the modern enterprise ERP system to meet the enterprise applicationoriented accounting personnel needs[8].

Promote the exchange of teachers, improve teacher and master of understanding curriculum system in the teaching process, clearly taught courses in the curriculum group in the network location, links and relationships with other courses, focus on training students should have in the level of professionalism, to prevent the generation of contradictory phenomena or repeated teaching in teaching system.

\section{CONCLUSION}

The Construction of 'Four Horizontal Lines and Four Vertical Lines" Curriculum Systems in College Accounting Major is the innovative construction of independent college accounting professional through vertical and horizontal linkages, but also need to constantly test and adjust the curriculum system of network based group, formed in the last step of accounting professional courses, practice tests. 
Found that the problem constantly revised and perfected, enhanced accounting professional course group rationality and applicability. And pay attention to the cultivation of students' application ability in the course of the system.

Increase innovation practice course type and improve the application ability of the students, to understand students and teachers' feedback through the issuance of questionnaires[9].

Constantly improve the teaching plan, through school enterprise cooperation and encourage student entrepreneurship form practice model diversification.

Detailed the "Four Horizontal Line and Four Vertical Line" curriculum systems in college accounting major. The professional course system in the teaching syllabus and teaching plan in accordance with the network system in order to repeat screening part and no connection part, adjustment and deletion of content.

\section{REFERENCES}

[1] David W. Wetter,Ludmila Cofta-Gunn,Jennifer E. Irvin,Rachel T. Fouladi,Kelli Wright,Patricia Daza,Carlos Mazas,Paul M. Cinciripini,Ellen R. Gritz. What accounts for the association of education and smoking cessation?[J]. Preventive Medicine,2004,40(4).

[2] Pan Chen,Kristen C. Jacobson. Longitudinal Relationships Between College Education and Patterns of Heavy Drinking: A Comparison Between Caucasians and African-Americans[J]. Journal of Adolescent Health,2013,53(3).

[3] Stephen Billett. Integrating learning experiences across tertiary education and practice settings: A socio-personal account[J]. Educational Research Review,2014,12.

[4] William Elliott,Johnny S. Kim. The role of identity-based motivation and solution-focus brief therapy in unifying accounts and financial education in school-related CDA programs[J]. Children and Youth Services Review,2013,35(3).

[5] Susan L. Robertson,Roger Dale. The social justice implications of privatisation in education governance frameworks: a relational account[J]. Oxford Review of Education,2013,39(4).

[6] Xuguang Guo,Wei Chen,Andy Yu. Is college education worth it? Evidence from its impacts on entrepreneurship in the United States[J]. Journal of Small Business \& Entrepreneurship,2016,28(1).

[7] Rufei Zhang. Enterprise Education Research In The Context Of Moral Training In Chinese Colleges[J]. Balkan Region Conference on Engineering and Business Education,2014,1(1).

[8] Michael Ben Jacob. Pedagogy of Financial Education among College Students[J]. Economics and Culture,2016,13(2).

[9] Rik Cheston. The Accounts of Special Education Leavers[J]. Disability \& Society,1994,9(1). 